\title{
Implementation of the Fiala-based thermophysiological model coupled with the Zhang regression model of human thermal comfort
}

\author{
Jan Pokorny ${ }^{*}$, Miroslav Jicha
}

From 15th International Conference on Environmental Ergonomics (ICEE XV)

Portsmouth, UK. 28 June - 3 July 2015

\section{Introduction}

Evaluation of thermal comfort in non-uniform and transient environments is still a challenging topic, which requires knowledge of human physiology and perception of the thermal environment. We present the Matlab implementation of the Fiala thermophysiological model [1] coupled with the empirical model of human thermal comfort [2]. Both models are designed for non-uniform and transient environments, e.g. transport vehicle cabins. The original Fiala model was re-implemented with some modifications into commercial software as Theseus-FE or RadTherm and it has been widely used by the research community; e.g. to develop individualized models [3], [4], for coupling with the CFD (Computational Fluid Dynamics) [5] or for real-time applications [6]. Nowadays, [7] the Fiala model is one of the most advanced models in the field of the human thermophysiology and thermal comfort (index DTS - Dynamical Thermal Sensation).

\section{Methods}

A mathematical background of the thermophysiological model is formed by the set of partial differential equations describing unsteady 1D heat transfer in living tissues. The set of equations was solved by the finite difference method using Crank-Nicolson scheme.

\section{Results}

We implemented the Fiala-based model in the Matlab and we verified it on the experimental data from the literature. We also created a coupling between the Fiala and Zhang model although with only partial success.

* Correspondence: pokorny.j@fme.vutbr.cz

Brno University of Technology, Energy Institute - Department of

Thermodynamics and Environmental Engineering, Czech Republic

\section{Discussion}

The main problem of the coupling is the different definition of a neutral thermal state of the human body, which varies by $2{ }^{\circ} \mathrm{C}$ in the case of central body parts. This problem was pointed out and discussed by Schellen, et al. [8].

\section{Conclusion}

The Fiala-based model was implemented into the Matlab and it was coupled with the Zhang regression model of thermal comfort. The prediction of the coupled models needs to be improved.

\section{Acknowledgements}

The research was supported by the project L01202 NETME CENTRE PLUS with the financial support from the Ministry of Education, Youth and Sports of the Czech Republic under the "National Sustainability Programme I" and the project of the Josef Bozek Competence Centre for Automotive Industry TE01020020.

\section{Published: 14 September 2015}

\section{References}

1. Fiala D: Dynamic simulation of human heat transfer and thermal comfort. Ph.D. Thesis, De Montfort University; 1998.

2. Zhang $\mathrm{H}$, et al: Thermal sensation and comfort models for non-uniform and transient environments: Part I: Local sensation of individual body parts; Part II: Local comfort of individual body parts; part III: Whole-body sensation and comfort. Building and Environment 2010, 45(2):380-410.

3. Lichtenbelt WDV, et al: Validation of an individualised model of human thermoregulation for predicting responses to cold air. International Journal of Biometeorology 2007, 51(3):169-179.

4. Miller T, et al: Dynamic Simulation of Human Thermoregulation and Heat Transfer for Spaceflight Applications. 41st International Conference on Environmental Systems Portland, Oregon, USA; 2011.

5. Cropper PC, et al: Coupling a model of human thermoregulation with computational fluid dynamics for predicting human-environment interaction. Journal of Building Performance Simulation 2010, 3(3):233-243.

6. van Treeck $C$, et al: Integrated thermal comfort analysis using a parametric manikin model for interactive real-time simulation. Journal of Building Performance Simulation 2009, 2(4):233-250. 
7. Fiala D, et al: UTCI-Fiala multi-node model of human heat transfer and temperature regulation. Int J Biometeorol 2012, 56(3):429-441.

8. Schellen $L$, et al: The use of a thermophysiological model in the built environment to predict thermal sensation: coupling with the indoor environment and thermal sensation. Building and Environment 2013, 59:10-22.

doi:10.1186/2046-7648-4-S1-A30

Cite this article as: Pokorny and Jicha: Implementation of the Fiala-based thermophysiological model coupled with the Zhang regression model of human thermal comfort. Extreme Physiology \& Medicine 2015 4(Suppl 1):A30.

Submit your next manuscript to BioMed Central and take full advantage of:

- Convenient online submission

- Thorough peer review

- No space constraints or color figure charges

- Immediate publication on acceptance

- Inclusion in PubMed, CAS, Scopus and Google Scholar

- Research which is freely available for redistribution

Submit your manuscript at www.biomedcentral.com/submit
C Biomed Central 